Chapter 8

\title{
Water Use and Drought Response in Cultivated and Wild Apples
}

\author{
Carole L. Bassett \\ Additional information is available at the end of the chapter \\ http://dx.doi.org/10.5772/55537
}

\section{Introduction}

Water availability is the single most important factor determining plant survival. Many environments experience water-limited periods of various degrees and duration. The issue of water availability for agricultural crops where maintenance of high yields over variable growing seasons is desirable is particular critical. For plants, the strategy choices for survival can be summarized as dehydration avoidance (e.g., deep rooting), dehydration tolerance (e.g., accumulation of osmoprotectants) and drought escape (e.g., reproductive completion before the dry season). Drought adaptation in most plants is controlled by complicated interactions between anatomy, physiology and biochemistry, all of which are directly or indirectly under genetic control [1-3].

\section{Water use efficiency and drought resistance}

All living organisms have evolved mechanisms for adapting to changes in their environment, whether biotic such as pest related, or abiotic such as physically effected. For plants this is especially challenging, since they are unable to relocate to avoid adverse conditions. As a result, numerous strategies employed by plants leading to successful acclimation have been identified. Broadly speaking, these adaptive mechanisms can be divided into two major categories, namely morphological modifications and physiological adjustments. Through combinations of these basic strategies, plants can respond quickly to environmental cues, often maintaining the response for relatively long periods [4,5].

The term drought resistance is sometimes confused with water use efficiency (WUE). Drought resistance is determined primarily by 'drought avoidance' (high plant water status maintained 
under water deficit) and/or 'drought tolerance' (capacity to sustain plant function in a dehydrated state) [6,7]. Drought resistance in a genetic/physiological context refers to the ability of one genotype to yield 'better' than another during severe drought stress. On the other hand WUE is defined as the ratio between diffusion of $\mathrm{CO}_{2}$ into the leaf (photosynthesis) and loss of $\mathrm{H}_{2} \mathrm{O}$ through transpiration, indicated as WUE $=\mathrm{A} / \mathrm{E}$, where $\mathrm{A}$ is carbon assimilation and $\mathrm{E}$ is transpiration. It is positively correlated with carbon isotope discrimination $\left(\Delta^{13} \mathrm{C}\right)$ based on the stable carbon isotope ratio, $\delta^{13} \mathrm{C}\left({ }^{12} \mathrm{C} /{ }^{13} \mathrm{C}\right.$ relative to a standard, i.e. PeeDee Belemnite), in the plant tissue relative to the atmospheric ratio and is calculated as: $\Delta^{13} \mathrm{C}=\delta^{13} \mathrm{C}$ in air $-\delta^{13} \mathrm{C}$ of the plant $/ 1-\delta^{13} \mathrm{C}$ of the plant. Since most gas exchange occurs via the stomata, it is expected that guard cell function would be closely associated with WUE. Indeed, the size and density of stomates correlates well with water use efficiency [8-10]. For drought resistance, yield is not necessarily adversely affected by resistance, whereas for WUE reduced transpiration through stomatal closure is often accompanied by reduced yield potential through reduced carbon assimilation, particularly in herbaceous $\mathrm{C}_{3}$ plants (however, see below). Other parameters, such as root depth, leaf size, and trichome size and density have also been linked to water use efficiency [2], but they have also been linked to drought resistance as well [6].

Different methods have been used to measure drought resistance and WUE [11]. These methods measure the energy status of water in plant tissues and the trans-port processes into and out of the soil-plant-atmosphere continuum. In general, these methods isolate specific plant tissues at instantaneous moments in time, whereas $\Delta{ }^{13} \mathrm{C}$ represents a time-integrated value of the ratio of $\mathrm{C}_{\mathrm{i}}$ (intercellular $\mathrm{CO}_{2}$ concentration) to ambient $\mathrm{CO}_{2}$ which, as previously indicated, reflects the plant's capacity for gas exchange via stomata [12] and discrimination of rubisco against ${ }^{13} \mathrm{C}$. The use of carbon isotope discrimination to select in-dividuals with higher WUE has been applied successfully to cereal breeding programs (13). The extent of $\delta^{13} \mathrm{C}$ varies substantially among wheat genotypes, and heritability is high because genotype $\mathrm{X}$ environment interactions are relatively low $[14,15]$. Rebetzke et al. [16] reported on the selection of plants with greater biomass, harvest index and kernel weight using results from contrasting high and low $\Delta^{13} \mathrm{C}$ groups in combination with a backcrossing program. There were significant correlations between $\Delta^{13} \mathrm{C}$ and yield and between $\Delta^{13} \mathrm{C}$ and biomass. The resulting high yielding strain, 'Drysdale', produces around 10\% more grain under drought conditions than other dry-area wheat varieties.

\section{Adaptation and the relationship of $\delta^{13} \mathrm{c}$ to yield}

Adaptive changes in populations growing in different environments have been amply demonstrated in a variety of plants [17]. Divergence among populations associated with different environments provides the raw material for speciation and differentiation among closely related species. Higher fitness of genotypes in their native environment compared to genotypes transplanted from contrasting environments provides evidence of local adaptation [9]. For example, when two populations of Boechera holboellii growing in xeric and wet environments were grown in reciprocal transplant experiments, significantly higher survival was observed with plants growing in their native habitat [18]. Furthermore, genes identified 
by cDNA-AFLP analysis showed genotype-specific expression patterns related to the indigenous environment (population). In another study populations of Encelia farinosa growing over a broad rainfall gradient in the deserts of southwestern North America, were evaluated for leaf characteristics. Leaf pubescence declined as mean water availability increased [19]. Variations among populations for both pubescence and carbon isotope discrimination persisted when the plants were grown in common environments differing in water availability, indicating a genetic basis for variation in these traits [20].

WUE in trees adapted to different environments has been documented in several forest species [21-24]. For example, a study of four birch (Betula pendula Roth) clones from environments with different rainfall amounts indicated strong clonal differences in a number of water use and photosynthetic traits, including leaf $\delta^{13} \mathrm{C}$ values [21]. A follow-up study correlated differences in leaf and root morphological parameters and carbon partitioning with clones from the drier environments [25]. Although individual leaf areas were smaller in drought-treated clones, regardless of their region of origin, total leaf and specific leaf areas (leaf area/leaf weight) were actually higher for the drought-treated clones from the drier environment. This is in contrast to the often observed reduction in leaf surface area seen in plants exposed to water deficit(WD) [26].

Poplar species are differentially adapted to a variety of environments, and because poplar is a rapidly growing tree with heavy water use, there is growing interest in developing lines that are drought resistant. Links between productivity and $\Delta^{13} \mathrm{C}$ varied in a study comparing different poplar genotypes, suggesting that genotypes displaying simultaneous high productivity and improved water use efficiency could be selected [27]. To obtain more practical information regarding productivity and WUE, a field study was conducted on the same genotypes analyzed in the previous study. Significant clonal diversity was observed for several traits related to productivity and for $\Delta$ which showed high heritability $(H 2=0.71)$ [28]. A lack of correlation between above ground biomass and $\Delta$ was reflected in several clones where high productivity was combined with improved WUE. This observation supports previous studies with cereals indicating that WUE and yield can be inherited as separate traits.

Yield of deciduous tree fruit crops is not measured as total biomass yield in commercial production as are agronomic crops such as corn, wheat and rice or forest trees. In commercial orchards it is common practice to reduce yield potential of fruit trees by as much as $50 \%$ to insure large fruit sizeandhigh fruitquality [29]. Consequently, the paradigm thatincreasedWUEis tied toreduced yield potential is notnecessarily valid for tree fruit production. For example, Glenn et al. [30] have demonstrated the practicality of identifying peach cultivars with high WUE withoutcompromising productivity. This study, taken together with those cited previously, demonstrates the feasibility of selecting for improved WUE without loss in productivity.

\section{Adaptation, WUE and $\delta{ }^{18} \mathrm{O}$}

Transpiration rate (E) affects water loss to the atmosphere and is negatively correlated with WUE. Despite the fact that atmospheric ${ }^{18} \mathrm{O}$ is low (ca. $0.2 \%$ of total oxygen), plants tend to accumulate ${ }^{18} \mathrm{O}$ and ${ }^{2} \mathrm{H}$ in leaf water due to the difference in vapor pressure between heavy 
water and 'normal' water and to differences in diffusivity with air. However, the relationship between $\mathrm{E}$ and isotopic enrichment is complex. For example, variation in $\mathrm{E}$ can be caused by changes in evaporative demand and/or changes in stomatal conductance, gs [31]. If the source of variation is evaporative demand, then as $\mathrm{E}$ increases, ${ }^{18} \mathrm{O}$ enrichment increases. On the other hand, if stomates are the source of variation, then as E decreases (stomates close), leaf water enrichment increases. How does this relate to ${ }^{18} \mathrm{O}$ enrichment of plant organic matter? Plants accumulate ${ }^{18} \mathrm{O}$ in their tissues as a result of the exchange of oxygen between water and carbonyl oxygens in triose phosphates. An enrichment of about 27 parts per thousand (ppt) has been observed in the organic material of several different plants relative to leaf water [32]. This suggests that differences in ${ }^{18} \mathrm{O}$ enrichment can be used to distinguish genotypes with favorable yields and stomatal function. In fact Barbour et al. [33] recently demonstrated a reliably negative correlation between yield and $\delta^{18} \mathrm{O}$ in wheat which was used to identify water use efficient varieties for breeding.

\section{Specific genes associated with WUE and/or drought responses in apple and other plants}

The recent advent of global gene expression methodology has spawned a number of studies of abiotic stress responses, including drought, in several plant species [34-38]. In Arabidopsis, a compilation study of microarray analyses on plants subjected to a variety of stress treatments highlighted overlap among genes up-regulated in the early stages of all the stress responses [39]. Studies on WD stress in cereals and dicots have cataloged a large number of genes upregulated during treatment [35-37, 40,43]. Comparisons among these studies reveal that a number of genes are reproducibly up-regulated in response to WD regardless of how the stress was imposed or what plant system was involved, including apple (Table 1) [44].

\section{Genes associated with wue}

Recent reports of genes associated with regulation of transpiration demonstrate the complexity of water use and transport, as well as the overlap in gene response to other stresses. ESKIMO1, which was originally associated with cold response, has recently been shown to affect both drought and salt responses in Arabidopsis. Insertional mutation lines inactivating ESK1 had reduced transpiration rates and were only slightly less drought tolerant than wild type [45]. Furthermore, there was a reduction in biomass when mutant plants were grown without stress, suggesting that alterations in WUE were reducing both transpiration and $\mathrm{CO}_{2}$ exchange; biomass differences between WT and esk 1 lines were negligible under stress. Another example of pleotrophic gene effects on plant physiology was reported in a study by Masle et al. [46]. A leucine-rich repeat receptor kinase (ERECTA) previously associated with inflorescence development was also shown to regulate transpiration in different races of Arabidopsis. The gene is implicated in epidermal cell expansion, cell-cell contact and mesophyll cell proliferation, but its relationship to reduced transpiration may be linked to differences in stomatal 


\begin{tabular}{cccc}
\hline $\begin{array}{c}\text { Genes Up-regulated in } \\
\text { 'Royal Gala' Roots }\end{array}$ & Other Plants & Tissue & Citation \\
\hline HMW HSP & Arabidopsis & various & {$[40]^{2}$} \\
& Poplar proteome & {$[41]$} & {$[40]$} \\
aquaporin & Arabidopsis & various & {$[35]$} \\
& barley & leaves and roots & {$[43]$} \\
protease inhibitor & maize & leaves and roots & {$[41]$} \\
\hline & Arabidopsis & white roots & {$[40,42]$} \\
\hline
\end{tabular}

${ }^{1}$ Apple ('Royal Gala') genes are from two SSH root libraries of water deficit-treated plants (manuscript submitted)

2 This citation is a review of several different studies of water deficit-response in Arabidopsis.

Table 1. Genes up-regulated in water deficit-treated apple roots vs other plants responding to water deficit ${ }^{1}$

density between lines. Interestingly, there was no compensation in biomass for the reduction in E, indicating that as with WUE and $\Delta^{13} \mathrm{C}$, there are workable strategies for increasing WUE without sacrificing carbon assimilation under normal growth conditions.

Using a suppression subtractive hybridization (SSH) approach to drought-responsive gene isolation in a commercial apple, 'Royal Gala', we identified numerous genes commonly found to be WD responsive in other plants. We also identified several up-regulated genes unique to apple roots (Table 2; manuscript submitted). Some of these genes may reflect the role of roots in nutrient transport during stress, including a copper chaperone and a high affinity nitrate transporter that is a putative Arabidopsis NRT2.4 homolog.

\begin{tabular}{ccc}
\hline & Genes Up-regulated in 'Royal Gala' & \\
\hline Roots & Bark & Leaves \\
\hline BYPASS1 & Anthocyanin reductase & Auxin/Aluminum-induced protein \\
\hline Serine acetyltransferase & GAST1-like gene & Proteasome maturation factor \\
\hline High affinity nitrate transporter & Asparagine synthetase & Asparagine synthetase \\
\hline NPR1 & Chloroplast membrane protein Tic40 & Glyoxylate aminotransferase \\
\hline
\end{tabular}

${ }^{1}$ These genes have not yet been reported as up-regulated in response to WD in these tissues of other plants.

Table 2. Genes uniquely up-regulated in WD-treated apple tissues ${ }^{1}$ 


\section{Genes associated with drought avoidance and escape}

An example of the rapid evolution of a drought escape mechanism (early flowering) was demonstrated in a population of Brassica napa subjected to a multiyear drought [47]. Comparison of seeds collected from individual plants before the drought with those obtained from the drought-affected population indicated a significant earlier onset of flowering in the latter population. This observation was further expanded in a study of quantitave trait loci (QTLs) in maize associated with flowering time $(V g t 1)$ where a cis-acting region upstream of a transcription factor was shown to be the link between a QTL and the early flowering trait [48]. The authors speculate that natural genetic variations in flowering time enabled the selection of maize lines adapted to a range of latitudes and growing seasons, including drought tolerance. Another study of natural variation in ecotypes of Arabidopsis [49] found a strong positive genetic correlation $(\mathrm{rG}=0.98)$ between $\delta^{13} \mathrm{C}$ (drought avoidance) and flowering time (drought escape). They also observed compelling evidence for pleiotropy in lines varying in FLOWERING LOCUS C, suggesting that correlated evolution of $\delta^{13} \mathrm{C}$ and flowering time could be partly explained by coordinated allele fixation altering both traits.

In alfalfa a gene encoding a zinc-finger motif is expressed in roots [50,51]. The protein encoded by Alfin 1 binds DNA at a specific cis-elemtent and is proposed to be a root growth regulator, as transgenic lines overexpressing the gene show enhanced root growth under both normal and high salt conditions [52]. These same transgenic lines were significantly more salt tolerant, and presumably more drought tolerant (high salt concentrations in the media decrease water uptake), althought drought tolerance per se was not measured.

\section{Genes associated with drought tolerance and resistance}

Studies of specific genes associated with dehydration responses have been conducted in a number of plants, and roles for many of these genes have been correlated with specific morphological or physiological traits known to be involved in drought resistance. Abscisic acid (ABA) signaling and stomatal function are correlated with WUE and drought resistance, so it is not surprising that several genes involved in ABA perception and stomata opening/ closing respond to severe dehydration. Two calcium-dependent protein kinases from Arabidopsis have been implicated in slow-type anion channel activation [53]. In the double mutants, $\mathrm{ABA}$ and $\mathrm{Ca}^{2+}$-induced stomatal closing were impaired, but not completely. These genes may contribute to a rapid $\mathrm{Ca}^{2+}$-reactive response resulting in stomatal closure, as opposed to the slower $\mathrm{Ca}^{2+}$-programmed response which maintains long-term stomatal closure. Similar studies have also implicated a G protein-coupled receptor, GCR1, in ABA signaling perception in guard cells and during seed germination [54]. To examine stomatal function in more detail, Klein et al. [55] used a T-DNA insertion disrupting AtMRP5, an ABC transporter in Arabidopsis. The mutants had reduced transpiration rates and showed increased water use efficiency. In a similar study using T-DNA insertion disruption of AtMRP4 (another type of $\mathrm{ABC}$ transporter), Klein et al. [56] found the mutant lines to be more drought susceptible. In a 
recent study of the effects of overexpressing or silencing early response to dehydration (ERD15) in Arabidopsis, Kariola et al. [57] observed decreased drought tolerance in the overexpressing lines, whereas the silenced lines were hypersensitive to ABA and showed enhanced tolerance to drought. This study also suggests a negative role for ERD15 in mediating stress-related ABA signaling.

The cuticle is an important barrier to moisture loss in plants, therefore genes associated with cuticle synthesis and turnover are expected to contribute to plant water status. A recent study in alfalfa demonstrated that increased wax production activated by a putative TF (transcription factor) [WXP1] also enhanced drought tolerance in transgenic plants [58]. Similar studies with other transcription associated factors have also demonstrated a correlation between increased wax synthesis and drought tolerance $[59,60]$.

Constitutive expression of a barley Group III LEA (late embryogenesis abundant) protein placed in wheat under control of the maize ubi1 promoter resulted in improved water use efficiency and higher total dry mass in the majority of transgenic lines [61]. Overexpressing a small molecular weight heat shock protein (HSP17.6) conferred drought tolerance in Arabidopsis transgenic lines [62]. The authors also demonstrated that HSP17.6 had chaperone-like activity and could protect citrate synthase from chemical denaturation. Taken together these studies emphasize the different mechanisms so far discovered that affect water use and drought resistance in plants and indicate that different genes in the same pathway may be used by plants to control WD responses.

\section{Regulation of pathways/signaling networks associated with dehydration}

Most studies of dehydration responsive signaling pathways implicate ABA directly in altering specific gene expression [63]. In fact genes that respond to ABA usually have multiple copies of an ABA response element (ABRE) or a combination of an ABRE with other motifs such as Myb, Myc or coupling elements [for example, 64]. A second pathway involves drought response element binding (DREB) proteins, particularly DREB2-encoding genes, and may also involve ABA indirectly [65]. A recent report on the isolation of a fourth CBF (CBF4) from Arabidopsis suggests that this TF only responds to drought, in contrast to observations reported for CBFs1-3 which respond to both cold and drought stress [66].

Compelling evidence indicates that the $\mathrm{ABA}$ pathway likely involves $\mathrm{Ca}^{2+}$ signal transduction as an early step and important relay system for dehydration responses. ABA can also increase reactive oxygen species through higher levels of $\mathrm{H}_{2} \mathrm{O}_{2}$ [67, reviewed in 68]. Other studies have suggested stress-responsive pathways that operate through osmotic sensing independently of ABA [69]. An osmotic sensor similar to bacterial two-component receptors has been identified in Arabidopsis [70]. The gene was able to complement several mutations in yeast osmosensors and activated the HOG1 response pathway through a mitogen-activated protein kinase. No doubt other signaling components, both ABA-dependent and independent, will be identified in the near future. 
Numerous studies support the existence of extensive cross-talk between plant hormone signaling pathways [71-74]. It is therefore expected that both the salicylic acid and Jasmonic acid (JA)/ethylene pathways indirectly influence the expression of genes that respond to drought. Along these lines an Arabidopsis mutant ( $r c d 1)$ belonging to the ADP-(ribosyl)transferase domain-containing subfamily of the WWE family exhibits reduced sensitivity to ABA, ethylene and Me-JA, suggesting that it acts at an integrative node in hormonal signaling regulating different stress-responsive genes [75]. $r c d 1$ is just one example of many where one gene participates in multiple pathways.

\section{Studies in Malus sieversii}

Genetic polymorphisms from twenty populations of $M$. sieversii in Xinjiang, China were analyzed with RAPD markers to assess genetic diversity [76]. Based on the bands generated with 42 randomly chosen primers, variation within a population $(83.1 \%)$ was higher than among populations $(16.9 \%)$. The authors conclude that $M$. sieversii is a rich source of genetic diversity.

Evaluation of six Malus species using a variety of morphological and physiological traits led to the conclusion that $M$. toringoides and $M$. sieversii were the most drought tolerant of those analyszed [77]. Measurement of root parameters indicated that $M$. sieversii root surface area decreased in response to drought to $\sim 25 \%$ of the well-watered control in contrast to $M$. toringoides roots which decreased to $\sim 43 \%$ of the control. On the other hand, root surface activity (absorption) declined the least in M. toringoides (17\%) compared to seiversii (33\%). When data from all the measurements were taken into consideration, $M$. toringoides and $M$. seiversii were the top two most drought resistant species.

A study of the contribution of rootstock source to drought resistance was conducted using 'Gale Gala' apple scions grafted onto Malus sieversii or Malus hupehensis roots [78]. Differential responses of the grafted material to drought stress were determined by a number of physiological and morphological traits. Typical reductions in biomass, growth rate and leaf area are observed under drought conditions, but $M$. sieversii showed smaller reductions in these traits during drought treatment than $M$. hupehensis. Furthermore, a larger increase in whole plant WUE was measured in grafts on $M$. sieversii rootstocks compared to M. hupehensis.

Problem Statement: Many of our agronomically important fruit trees are derived from a rather narrow genetic base. To provide methods for enhancing apple germplasm resistance to drought and other dehydrative abiotic stresses it is imperative that we identify those genes that contribute to drought survival. Once these genes are identified and characterized they can be used in marker assisted selection strategies or altered by genetic engineering.

Application Area: The origin of the domesticated apple is believed to be in Central Asia via the silk route through Kazakhstan [79]. The predominant species contributing to the domestication of the modern apple is believed to be Malus sieversii which is thought to be the progenitor of $M$. $\times$ domestica and a possible source of resistance alleles lost during domestication 
[80]. A significant secondary contributor to the genetics of current apple varieties is the European crabapple, Malus sylvestris [79] which may also possess important resistant genes lost in the modern varieties.

Several studies of M. sieversii material collected from geographically and climatologically different sites in Kazakhstan have concluded that significant genetic diversity can be captured in small-sized sub-populations of these site collections [81, 82]. In a subsequent study of the Kazakhstan collection, Richards et al. [83] concluded that differentiation in genetic diversity was greater among individual families than among sites and that gene diversity and allelic richness varied significantly among collection sites. The use of this material to study drought responses in apple at the morphological and genetic levels without the complication of grafted rootstocks provides the cornerstone of our approach to identifying novel drought resistant mechanisms or factors contributing to drought susceptibility.

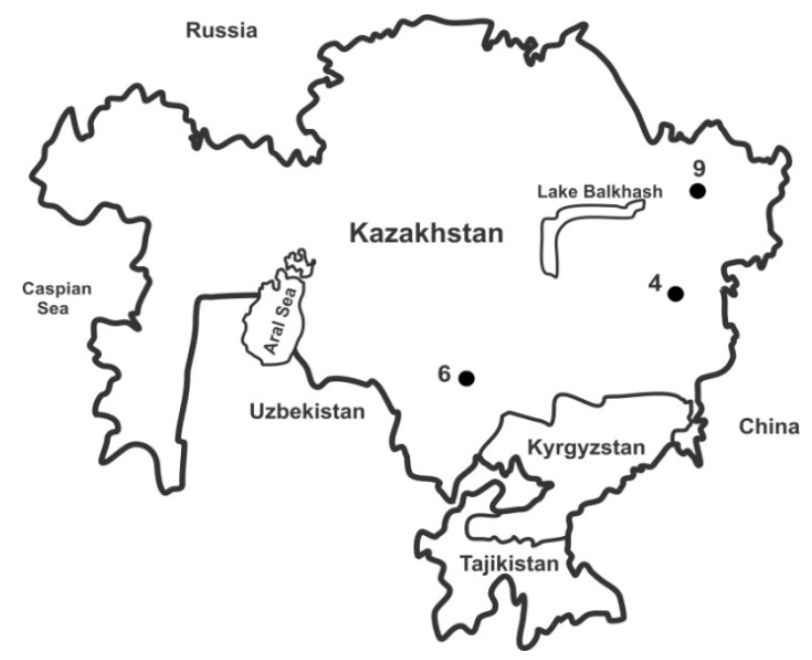

Figure 1. Malus sieversii collection sites in Kazakhstan [after 80]

Research Course: In order to isolate and characterize genes responding to drought from a commercially important cultivar as a standard for comparison, we used SSH on cDNA prepared from 'Royal Gala' subjected to a moderate-severe drought. Genes identified by this method were further characterized for their expression in various tissues under drought treatment or in fully watered controls.

To begin analyzing $M$. sieversii lines for drought responsiveness, we first surveyed core populations of individuals collected from xeric site 6 and later, xeric site 9 for WUE using stable carbon isotope composition $\left({ }^{13} \mathrm{C}\right)$ to identify individuals with better WUE. Morphological features, e.g. leaf area, leaf length, stomatal density and number of leaves per current year's branch length were evaluated [84]. Individuals showing $\delta{ }^{13} \mathrm{C}$ extreme values were then 


\begin{tabular}{|c|c|c|c|c|c|c|c|}
\hline $\begin{array}{l}\text { Individual } \\
\text { Seedling ID }\end{array}$ & Site $^{a}$ & Rainfall ${ }^{b}$ & $\delta^{13} C^{c}$ & $\begin{array}{c}\text { Fire } \\
\text { Blight }\end{array}$ & $S c a b^{d}$ & Juiciness & Surface Russet \\
\hline GMAL3975.k & 6 & $250 \mathrm{~mm}$ & $-27.09 p p t$ & $\mathrm{R}$ & $\mathrm{R}$ & dry & 0 \\
\hline GMAL3685.e & 6 & $250 \mathrm{~mm}$ & $-29.30 p p t$ & $\mathrm{R}$ & S & dry & $10 \%$ \\
\hline GMAL3623.f & 9 & $450 \mathrm{~mm}$ & $-26.33 p p t$ & $S$ & S & moderate & $1 \%$ \\
\hline GMAL4455 & 4 & 800 mm & $-26.30 p p t$ & $\mathrm{R}$ & $\mathrm{R}$ & medium & $20 \%$ \\
\hline \multicolumn{8}{|c|}{ a Geographical location of populations in Kazakhstan. } \\
\hline \multicolumn{8}{|c|}{${ }^{c} \mathrm{ppt}=$ parts per thousand; differences of $0.5 \mathrm{ppt}$ are significant. } \\
\hline
\end{tabular}

Table 3. Example of phenotypic diversity of select lines from M. sieversii Kazakhstan populations

clonally propagated for simulated drought experiments where photosynthesis and stomatal conductance were determined and roots, bark and leaves were collected for gene expression analysis. We duplicated these studies using 'Royal Gala', a relatively drought tolerant variety for comparison [85].

Methods Used: We used standard methods for the morphological and physiological measurements. For the drought experiments, young trees ( 1 $\mathrm{m}$ tall) of 'Royal Gala' propagated by shoot proliferation were grown for several weeks in a controlled environment with standard light and temperature conditions [44]. A simulated moderate-severe drought were imposed by withholding water until the pots reached $40 \%$ of full saturation and maintained for 2 weeks at this level after which the trees were sampled. A parallel control group was grown under the same conditions, but watered to full capacity every other day. Samples from roots, bark and leaves (fully expanded) were taken and quickly immersed in liquid $\mathrm{N}_{2}$. Roots were washed for $5 \mathrm{~min}$ in room temperature tap water, blotted dry and placed in liquid $\mathrm{N}_{2}$. Bark was removed by scraping the outer layers (down to the xylem) directly into liquid nitrogen. All samples were stored at $-80^{\circ} \mathrm{C}$ until use. Bark was lyophilized prior to storage at $-80^{\circ} \mathrm{C}$.

Total RNA was isolated, cDNA prepared and SSH performed using the protocol reported by Bassett et al. [86] for peach. For gene analysis, we designed primers for several genes shown to be associated with dehydration responsiveness in apple [44; manuscript submitted]. Each primer pair was quality tested and used to prime RT-qPCR reactions in order to quantitate gene expression in different tissues. The qPCR reactions were conducted using a kit containing all reagents (Life Technologies, Applied Biosystems, Grand Island, NY) and the reaction parameters were as follows: $95^{\circ} \mathrm{C} 5 \mathrm{~min}$, followed by 35 cycles of $95^{\circ} \mathrm{C} 1 \mathrm{~min}, 60-65^{\circ} \mathrm{C} 1 \mathrm{~min}$, $72^{\circ} \mathrm{C} 1 \mathrm{~min}$ and a final extension of $72^{\circ} \mathrm{C}$ for $10 \mathrm{~min}$. Primers for a translation elongation factor (TEF2) was used as an internal control for the qPCR experiments [87]. The relative standard curve method was used to analyze the data. 


\subsection{Status and results}

Analysis of 'Royal Gala' response to a simulated moderate-severe drought: Clonally replicated individuals growing on their own roots were generated for the suppression subtractive hybridization experiments. We identified several hundred different genes upregulated or down-regulated in roots, bark and leaves when DNA from drought-treated tissues served as 'tester' and DNA from well watered controls acted as 'driver' (10-fold higher amount). Some genes unique to our experiments that increased in response to drought are shown in Table 2. A number of drought-responsive genes were common to genes isolated from other plants systems, both dicot and monocot. Figures 2-4 show the relative expression of some of the common and unique genes in apple roots, bark and leaves.

Most of the genes examined regardless of tissue origin showed around a two-fold difference between watered and water-deficit treaments. A few genes were substanitally up-regulated in response to drought. including the auxin-induced gene from leaves (8-fold increase) and asparagine synthase from bark (4-fold increase). A few genes in roots were also significantly up-regulated in response to drought treatment, one of which was NPR1 (3-fold increase; manuscript submitted). From this information, including the expression of genes not shown here, we have generated a list of potential up-regulated genes responding to a relatively long term drought that can be used to determine if there is any correlation of expression in $M$. sieversii lines with high and low WUE values.

\subsection{Promoter comparison of NRT2.4 from apple, peach and Arabidopsis}

A high affinity nitrate transporter gene from the 'Royal Gala' root SSH library (see Table 2) was shown by RT-qPCR to be elevated in roots and bark in response to drought treatment (manuscript submitted). Approximately 700 bp upstream of the ATG start codon was obtained from the genomic sequence of 'Golden Delicious' (Genome Database for Rosaceae; http:// www.rosaceae.org/). Several cis-elements associated with tissue specificity or stress response were identified. To identify elements preserved during evolution, promoter regions from peach NRT2.4 and an Arabidopsis AtNRT2.4 gene were analyzed for comparison (Figure 5). All three genes contained consensus, well defined TATA boxes within 80-100 bp of the translation start. A number of MYB and MYC binding sites were identified in similar positions in all three promoters. The peach promoter was missing a root-specific element seen in both MdNRT2.4 and AtNRT2.4. Interestingly, both the apple and peach promoters contained a drought responsive element on the reverse strand. Overall the elements identified in the apple NRT2.4 promoter are consistent with the expression analysis results.

Screening the $M$. sieversii population at site 6 in Kazakhstan: A core diversity population of $M$. sieversii trees (34 individuals representing 14 sibling groups) collected from Kazakhstan site 6 and maintained as seedlings at the Geneva, NY ARS Plant Genetic Resources Unit, was sampled for stable carbon isotope discrimination to select individuals with extreme values compared to 'Royal Gala'. The results are shown in Figure 6. Two individuals from each end of the WUE spectrum were chosen for further characterization. 


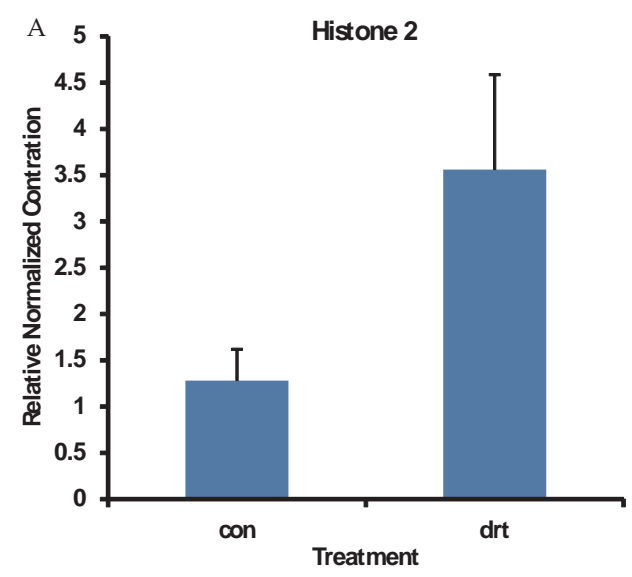

B

Major Latex

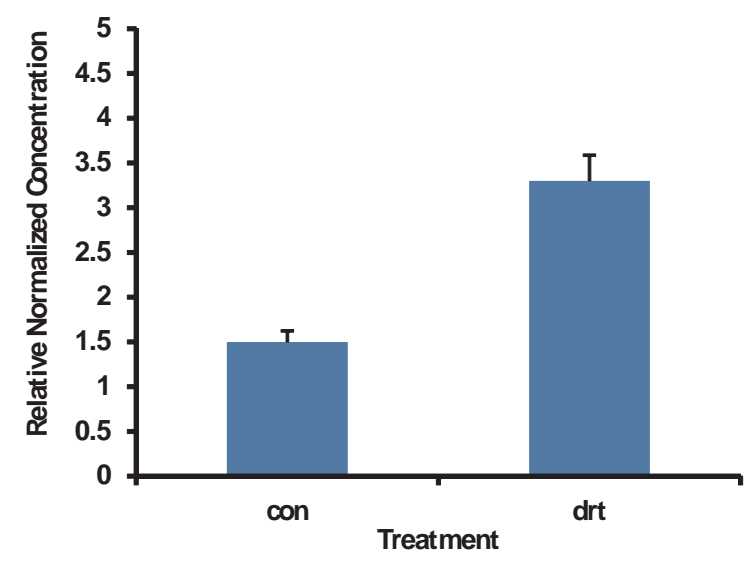

Figure 2. Relative expression of root genes up-regulated by drought treatment. Experiments were conducted as described in Methods. Test transcripts were normalized against TEF2. con: well watered controls; drt: treated to $40 \%$ saturation for two weeks. A: relative expression of Histone $\mathrm{H} 2 \mathrm{~b}$ gene; B: relative expression of the Major Latex protein gene.

M. sieversii lines GMAL4002.e and GMAL3975.k were propagated by shoot proliferation techniques to obtain a number of clonal individuals on their own roots. At the same time, 'Royal Gala' was propagated as a standard for comparison. Individuals from each line (4-6 trees per treatment) were acclimated under controlled conditions of light, water, fertilizer and temperature. Water was withheld from half of each group, while the other half received sufficient water to saturate the pot. The water-deficit trees reached $40 \%$ of pot saturation in about 7-10 days, at which time the individual plant and a comparable control were tagged. At the end of two weeks of treatment, the plants were individually sampled. Out of six 

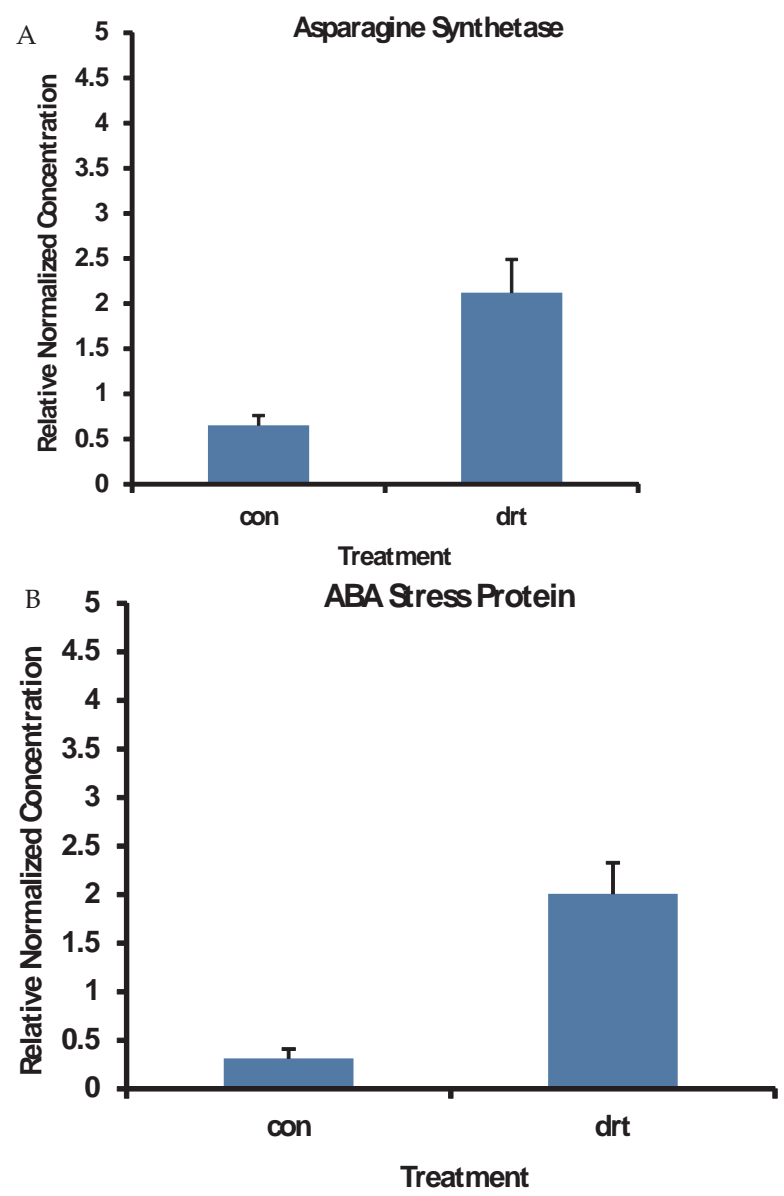

Figure 3. Relative expression of bark genes up-regulated by drought treatment. Experiments were conducted as described in Methods. Test transcripts were normalized against Actin. con: well watered controls; drt: treated to $40 \%$ saturation for two weeks. A: relative expression of asparagine synthetase gene; B: relative expression of an ABA stress protein gene.

GMAL4002.e plants, four began to show signs of severe wilting within a few days after reaching $40 \%$ as illustrated in Figure 7. This is consistent with WUE measurements which indicated that this particular line was not adept at maintaining healthy water status under the water deficit regime. Well watered GMAL4002.e controls showed no signs of wilting throughout the experiment. In contrast, GMAL3975.k with a WUE close to that of 'Royal Gala' showed no signs of wilting under the well-watered regime or water deficit stress (Figure 6). These results indicate that WUE can be used to identify apple lines that are drought sensitive, as well as drought tolerant. 


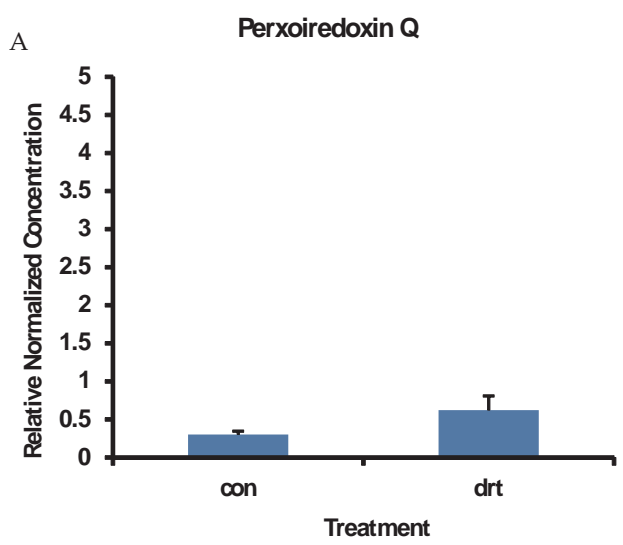

B

Auxin-responsive protein

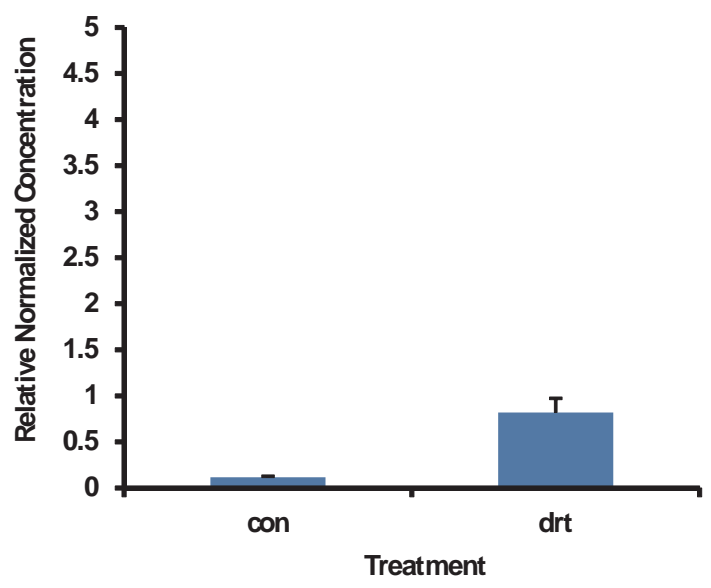

Figure 4. Relative expression of leaf genes up-regulated by drought treatment. Experiments were conducted as described in Methods. Test transcripts were normalized against Actin. con: well watered controls; drt: treated to $40 \%$ saturation for two weeks. A: relative expression of a peroxiredoxin gene; B: relative expression of an auxin-responsive/ ripening protein gene.

Leaf size and number have been shown to respond negatively to drought, resulting in longer intervals between newly initiated leaves and smaller sizes, all features designed to reduce transpiration to conserve water. Leaf morphological features and stomatal characteristics were examined in the site 6 subpopulation [84]. GMAL3683.o had the smallest leaves by all traits measured, whereas GMAL3687.d and GMAL3989.f had the largest leaves by area. Within the GMAL3683 sibling group, GMAL3683.o leaf area $\left(8.3 \mathrm{~cm}^{2}\right)$ clearly segregated from the other three members (average $=20.3 \mathrm{~cm}^{2}$ ).

Stomatal density has also been linked to drought tolerance and sensitivity. Therefore, we also examined stomata size and density in the site $6 \mathrm{M}$. sieversii population. GMAL3691.m had the 


\section{A}

-710 AgGTGTCATTTTCAAATACATCTCACATGCATTTCTAATGCTCATAGAGGTCATTACTAATCTCTTCTAA

-640 TCTTATATTTTATGGCCCATTTCTTACTAAACTTTAACICAATTCTTTGTGACTTAGGATATCATCTAACA

-570 TAGCCTCAATATGCGCTTCGGACGAGCAATTTCAAGACTCATGCAAATTCTTCGATTACAAGTGGGCAAA

-500 GTACAATGTTACAGATTGCATTATTAACCAATCAAAGTGGATCATTTACTAGTTGTATÄTÄTÄTAATTTA

- 430 GGTTTATGAAGCCAAGCATTACTCCAAACAAACAATATTCAAATATAATTTCCTTTGACGTGTGCAAATT

- 360 CCGGGCCGACTTAATTATTAGGAGTTCATTGACTTAGTTAATACTTGGTTGTCCCTAAGATGCAAGACAG

-290 ITGTTAATTAACCAGCTGATTGCAATTTTGAAGGGTTACTGTGATCCCTTGGGATATTCGATGAGACTTT

- 220 TACTATTCATATCATCGTATGCGGCGAACTGGATCACACAAATGTGGAGAATCTTACTCTTGCCCGTTGC

-150 CCCTTCACAACCCTCCACAACGTCAACTCCAAGCCCTATÄTAÄÄTCCCACACTCCCTTTGTACCTTCCTC

- 80 ACACAACACTACAATTCCGTTTAGTACTCTAATCAGCATCAAAATCCAAACCCCAAACCCCGAATTCCGA

-10 AGCCCCAAAAatg

\section{B}

$-710$

$-640$

$-570$

$-500$

$-430$

$-360$

$-290$

$-220$

$-150$

$-80$

$-10$

C

$-710$

$-640$

$-570$

$-500$

$-430$

$-360$

$-290$

$-220$

$-150$

$-80$

$-10$

TTAACATTCTTCTCTGAAAAATAAATAAAAGgTGTTTGTTTTAAAGTTAGAGAATCATTTTTTGTAGACT TGCAGTGCTTCTCTACGTAACACTGTGTGTGTTCTTTTTTGATGAGATAGGGGGGACAAAACCCAAAAGA GAACTGTGTGTGTTCTTTATGAAGTCTTCTCTTGATAAAAAGAGTTATTGAATGGAAGGGTTTGCTACAA AAACACTTGTTATTTTACTACAAAGTGTACAAAACAATAAATAAATAAAAGCTATATAAATCTGTATGTC ATATCATCTGTAATACTCTAACCATTTTACAGTGGTCCATGGAACGTGCAATGTGTACAAATCCCAA GCC GAGTTCATTAGGGTTCATTGACTTAATTAATTTTTGATTATCCTAATTATATGCGGCTACCAGTTAGTIA ACCAGCTGGATGGCCCATTAGGGAAGGTTTATGTGATCCCTTGGGATATACGATGAGACTTTTCCTG TT̄ ACATAAGATGCGGCAAAATGGATAACAAAAGTGTTGAGAATCTTTCCTTGCCTCTTCATAACCCTTCACA CAATGTCAACTCCAAGCCCTATATAAATGCCACACTCCCATATACTTTCCCCACACAACCCTAGAACTTC ATTTAGTCTAAGTAGTTTCTAAATTCGAAACTCGAGTTTTGAAACTCGAGATTCAAAATCCAAACTCCAA ACCCCAAATAatg

CAATCTTCCTAAgCATAATTAggGATCTgATTACATCATCACAACTTTAgTTTAATAAgTGAAAATCTAT ATATTATTTTGTTTATTTCAATAACATTCTATTATATTAACAAAAAAAAAAAAAAAATCAAATGGAACCT TTGAATCCATGCAAAGACATAGTCACATAGAGAGAGAGAGGACCCACCGCGTTCACATGTATGAATATGG ATTGATAGTAAACTCTATGAGGATTTGCTGTATTAGACATGAAAAGAAATCGT'T̄'TĀĀĀCAGAACCAGAA AGTAGTTTCTCGTTTGAGAAAAAAAAAAAAAAAAAAAACTTCCTAGATATATGGACAGTTTAGTAATATT ATATTGTTGATAAATACTAAATTGGAATATAAGTGAAAGTGAACCTTTGGGACGTATGACCAGGCTAAAT

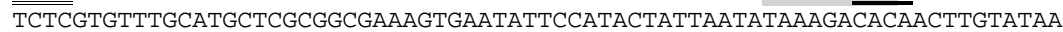
TTGTAATCAATCTCACATAAACAACTTTGAATCATTAATTATCGTTAAGAACTATACTATTATAGTATCA TTTACGTAAAACGAATCCCACTTATAGCCTTTTCGAATCTCCATCGGCTCTTACGAAGTCAACTTTCGTA TCTCTATATAAAACCATTCTTCTCCTTCTTGTTCCCTAAACCAAGACCACAAGAAAAAAACATAAAAAAA TATT $\overline{\overline{C A C A A A a t g}}$

Figure 5. Figure 5. Comparison of NRT2.4 promoter regions from apple and Arabidopsis. Only the first 700 bases upstream of the translation start (atg) are shown. Cis-elements were identified by PLACE [88] and PLANTCare [89]. A: Promoter region from apple MdNRT2.4; B: Promoter region from peach genome; C: Promoter region from Arabidopsis AtNRT2.4. AAACAAA: anaerobic induction [90]; TGACG: WRKY stress responsive binding element $\left[91\right.$ ]; $\mathbf{A}^{\mathbf{A}} / \mathbf{C} \mathbf{G T C A}$ and $/{ }_{A}$ GACTTTTC: bZIP and NF-B binding sites, respectively [92]; CAAGCATGCTTCTTGC: consensus root-spscific element [93]; TATA box: Polll binding; TCATTACTAA: wound-inducible element [94]; ACGTG/AT: ABRE core element [95]. An element of unknown function in the Arabidopsis NRT2.4 gene promoter (GTCAACT) is also present in the MdNRT2.4 and peach promoters. A cis-element for hypoosmolarity-responsiveness [96] is identified by an oval. Dashed underlines indicate a MYB (WAACCA) binding site [97] and MYC core sequences (CANNTG); fuschia-underlined MYC element on the negative strand in A and B (CAACTG) is associated with drought response [73]. A CBF/DREB element $[98,99]$ is boxed in A and B.

largest stomates, whereas GMAL3684.a had the smallest. GMAL3689.n had the highest density of stomates (58 per $0.09 \mathrm{~mm}^{2}$ ); GMAL3685.e had the lowest density (23 per $0.09 \mathrm{~mm}^{2}$ ). There was no correlation between leaf and stomate features in the M. sieversii site 6 population, nor was there a correlation between the leaf and stomate extreme values and the ${ }^{13} \mathrm{C}$ extreme values. 


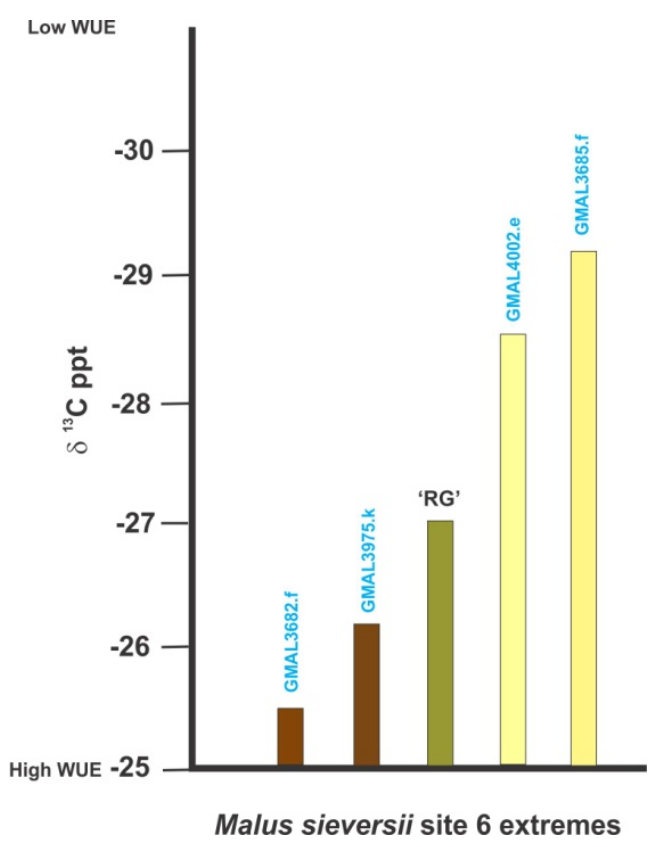

Figure 6. Stable carbon isotope analysis of select $M$. sieversii individuals from the site 6 population Measurements were made from branches representing current year's growth. Collection of samples was made from dormant trees for three years and averaged. RG: 'Royal Gala' standard.

In other words, although leaf and stomate physical characteristics might contribute to the drought response of $M$. sieversii individuals from site 6, another mechanism(s) appears to better explain the WUE data.

Further Research: The overall goal of this project is to link drought responsiveness and/or WUE to specific apple genes. To this end we are interested in candidate genes that are either up-regulated in response to drought (drought 'defensive' genes) or down-regulated (drought survival 'assisting' genes). The latter can be used to identify genetic alterations that could hamper the physiological state attained by up-regulated genes and therefore to be avoided in breeding programs. Up-regulated genes are of interest because of their obvious association with drought resistance. We have developed primers for many of the drought up-regulated genes identified in 'Royal Gala' and have tested them against individual lines of M. sieversii. Experiments to quantify their expression in the roots, bark and leaves of the site 6 lines representing WUE extremes are currently underway. We are also replicating additional $M$. sieversii lines on their own roots for simulated drought experiments like the ones shown in Figure 7 to provide physiological, morphological and molecular biological data to detect associations to drought resistance or susceptibility. Since the M. sieversii site 6 and 9 populations have undergone rapid adaptation to the xerophytic environments they currently occupy, it seems likely that alterations in patterns of expression could account for their survival. To 


\section{Days of Simulated Drought}

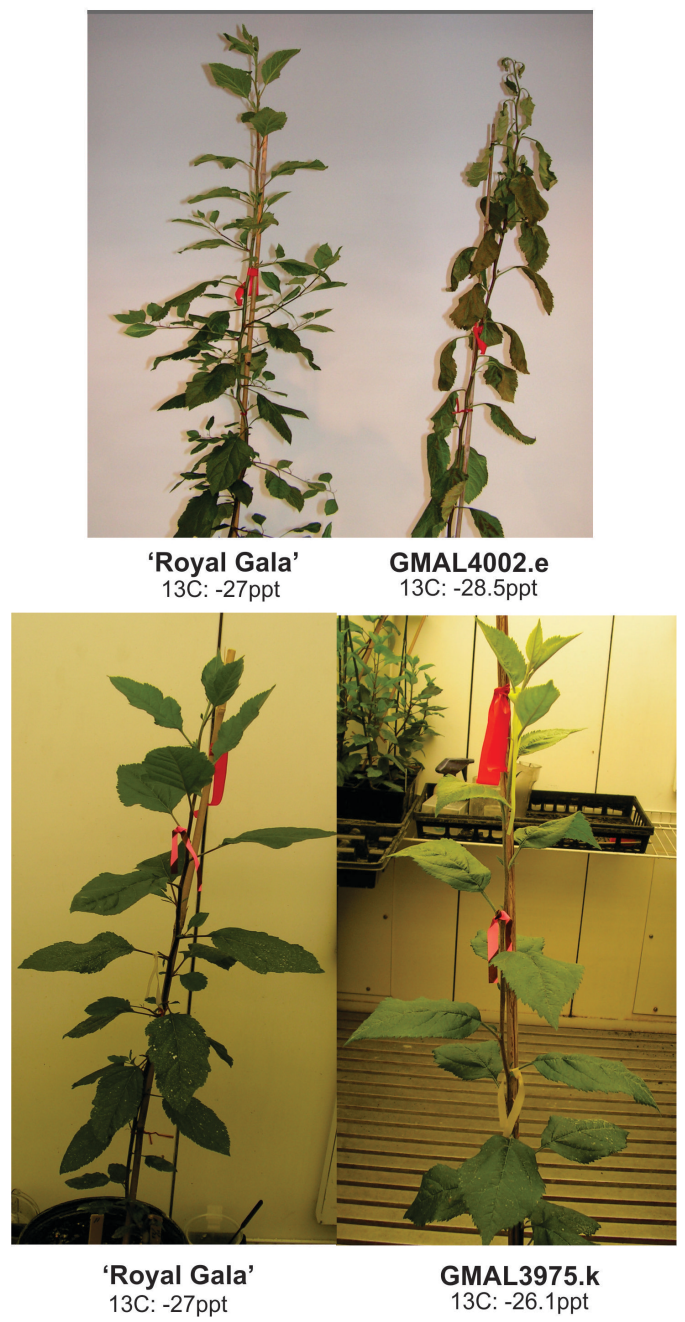

Figure 7. 'Royal Gala' and different $M$. sieversii genotypes under severe water deficit conditions. Delta ${ }^{13} \mathrm{C}$ values are included under the cultivar/genotype name. A difference of $0.50 \mathrm{ppt}$ is considered significant. Note the wilting observed with GMAL4002.e compared to 'Royal Gala' under identical SD conditions. Also note GMAL3975.k and 'Royal Gala' respond similarly to the SD. $13 \mathrm{C}=\delta 13 \mathrm{C}$

this end we are planning experiments to determine the kinetics of expression of candidate genes over a broader time period in select $M$. sieversii lines. Finally, we plan to examine promoter elements for single nucleotide polymorphisms or other alterations that might influence expression and to identify changes in methylation that might contribute to differences in expression between the more drought resistant lines and those that are more sensitive. 
The information generated from these experiments can be used in breeding programs to select drought resistant progeny using marker assisted selection. In addition the use of genetic engineering of select genes is another potentially successful approach to obtaining new varieites with improved drought resistance or enhanced WUE. With increasing competition between agriculture and urban populations for fresh water and with climate change which predicts increasing episodes of intense drought periods worldwide, there is a critical need for the development of crop varieties with more efficient use of water and the ability to survive longer drought periods. Since apples are a good source of nutrition and can be conveniently stored and shipped, they are a logical target for improvement.

\section{Author details}

Carole L. Bassett

Research Molecular Biologist, USDA, Agricultural Research Service, Appalachian Fruit Research Station, Kearneysville, WV, USA

\section{References}

[1] Bohnert HJ., Nelson DE. and Jensen RG. Adaptations to environmental stresses. The Plant Cell 1995; 7(7):1099-111.

[2] Ingram J. and Bartels D. The molecular basis of dehydration tolerance in plants. annual review of Plant physiology and plant molecular biology 1996; 47:377-403.

[3] Street NR., Skogstrom O., Sjodin A., Tucker J., Rodriguez-Acosta M., Nilsson P., Jansson S. and Taylor G. (2006) The genetics and genomics of the drought response in populus. plant journal 2006; 48(3):321-341.

[4] Bogeat-Triboulot M-B., Brosché M., Renaut J., Jouve L., Le Thiec D., Fayyaz P., Vinocur B., Witters E., Laukens K., Teichmann T., Altman A., Hausman J-F., Polle A., Kangasjärvi J. and Dreyer E. Changes of gene expression, protein profiles, ecophysiology and growth performance in Populus euphratica, a poplar growing in arid regions. Plant Physiology 2007; 143(2):876-892.

[5] Maseda PH. and Fernández RJ. Stay wet or else: three ways in which plants can adjust hydraulically to their environment. Journal of Experimental Botany 2006; 57(15): 3963-3977.

[6] Blum A. Drought resistance, water-use efficiency, and yield potential: are they compatible, dissonant, or mutually exclusive? Crop \& Pasture Science (formerly Australian Journal of Agricultural Research) 2005; 56(11):1159-1168. 
[7] Levitt J. Responses of plants to environmental stresses. New York: Academic Press; 1972.

[8] Dudley SA. Differing selection on plant physiological traits in response to environmental water availability: A test of adaptive hypotheses. Evolution 1996; 50(1):92-102.

[9] Dudley SA. The response to differing selection on plant physiological traits: Evidence for local adaptation. Evolution 1996; 50(1):103-110.

[10] Monclus R., Dreyer E., Villar M., Delmotte FM., Delay D., Petit J-M., Barbaroux C., Le Thiec D., Bréchet C. and Brignolas F. Impact of drought on productivity and water use efficiency in 29 genotypes of Populus deltoides $\times$ Populus nigra. New Phytologist 2006; 169(4):765-777.

[11] Kramer PJ. and Boyer JS. Water Relations of Plants and Soils. New York: Academic Press; 1995.

[12] Farquhar GD., Ehleringer JR. and Hubick KT. Carbon isotope discrimination and photosynthesis. Annual Review of Plant Physiology and Plant Molecular Biology 1989; 40:503-537.

[13] Richards RA., Rebetzke GJ., Condon AG. and van Herwaarden AF. Breeding opportunnities for increasing the efficiency of water use and crop yield in temperate cereals. Crop Science 2002; 42(1):111-121.

[14] Condon AG. and Richards RA. Broad sense heritability and genotype x environment interaction for carbon isotope discrimination in field-grown wheat. Crop \& Pasture Science (formerly the Australian Journal of Agricultural Research) 1992; 43(5): 921-934.

[15] Condon AG., Richards RA., Rebetzke GJ. and Farquhar GD. Improving intrinsic water-use efficiency and crop yield. Crop Science 2002; 42(1):122-131.

[16] Rebetzke GJ., Condon AG., Richards RA. and Farquhar GD. Selection for reduced carbon-isotope discrimination increases aerial biomass and grain yeild of rainfed bread wheat. Crop Science 2002; 42(3):739-745.

[17] Ackerly DD., Susley SA., Sultan SE., Schmitt J., Coleman JS., Linder CR., Sandquist DR., Geber MA., Evans AS., Dawson TE. and Lechowicz MJ. The Evolution of Plant Ecophysiological Traits: Recent Advances and Future Directions. BioScience 2000; 50 (2) 979-995.

[18] Knight CA., Vogel H., Kroymann J., Shumate A., Witsenboer H. and Mitchell-Olds T. Expression profiling and local adaptation of Boechera holboellii populations for water used efficiency across a naturally occurring water stress gradient. Molecular Ecology 2006; 15(5):1229-1237. 
[19] Sandquist DR. and Ehleringer JR. Intraspecific variation of leaf pubescence and drought adaptation in Encelia farinosa associated with contrasting desert environments. New Phytologist 1997; 135(4):635-644.

[20] Sandquist DR. and Ehleringer JR. Intraspecific variation of drought adaptation in brittlebush: Leaf pubescence and timing of leaf loss vary with rainfall. Oecologia 1998; 113(2):162-169.

[21] Aspelmeier S. and Leuschner C. Genotypic variation in drought response of silver birch (Betula pendula Roth): leaf water status and carbon gain. Tree Physiology 2004; 24(5):517-528.

[22] Bonal D., Sabatier D., Montpied P., Tremeaux D. and Guehl J-M. Interspecific variability of delta ${ }^{13} \mathrm{C}$ among trees in rainforests of French Guiana: functional groups and canopy interactions. Oecologia 2000; 124(3):454-468.

[23] Brendel O., Pot D., Plomion C., Rozanberg P. and Guehl J-M. Genetic parameters and QTL analysis of delta ${ }^{13} \mathrm{C}$ and ring width in maritime pine. Plant, Cell \& Environment 2002; 25(8):945-953.

[24] Ponton S., Dupouey J-L., Bréda N., Feuillat F., Bodenes C. and Dreyer E. Carbon isotope discrinimation and wood anatomy variation in mixed stands of Quercus robur and Quercus petraea. Plant, Cell \& Environment 2001; 24(8):861-868.

[25] Aspelmeier S. and Leuschner C. Genotypic variation in drought response of silver birch (Betula pendula Roth): leaf and root morphology and carbon partitioning. Trees 2006; 20(1):42-52.

[26] Mäkelä A., Berninger F. and Hari P. Optimal control of gas exchange during drought: theoretical analysis. Annals of Botany 1996; 77(5):461-467.

[27] Marron N., Villar M., Dreyer E., Delay D., Boudouresque E., Petit J-M., Delmotte FM., Guehl JM. and Brignolas F. Diversity of leaf traits related to productivity in 31 Populus deltoides $\times$ Populus niger clones. Tree Physiology 2005; 25(4):425-435.

[28] Monclus R, Dreyer E, Delmotte FM, Villar M, Delay D, Boudouresque E, Petit J-M, Marron N, Bréchet C and Brignolas F. Productivity, leaf traits and carbon isotope discrimination in 29 Populus deltoides $\times$ P. nigra clones. New Phytolologist 2005; 167(1): 53-62.

[29] Dennis FG., Jr. The history of fruit thinning. Plant Growth Regulation 2000; 31(1): $1-16$.

[30] Glenn DM., Scorza R. and Okie WR. Genetic and environmental effects on water use efficiency in peach. Journal of the American Society for Horticultural Science 131(2): 290-294.

[31] Farquhar GD., Cernusak LA. and Barnes B. Heavy water fractionation during transpiration. Plant Physiology 2007;143(1):11-18. 
[32] Barbour MM., Fischer RA., Sayre KD. and Farquhar GD. Oxygen isotope ratio of leaf and grain material correlates with stomatal conductance and grain yield in irrigated wheat. Australian Journal of Plant Physiology 2000; 27:625-237.

[33] Barbour MM., Fischer RA., Sayre KD., Farquhar GD.. Oxygen isotope ratio of leaf and grain material correlates with stomatal conductance and grain yield in irrigated wheat. Australian Journal of Plant Physiology 2000; 27: 625-637.

[34] Houde M., Belcaid M., Ouellet F., Danyluk J., Monroy AF., Dryanova A., Gulick P., Bergeron A., Laroche A., Links MG., MacCarthy L., Crosby WL. and Sarhan F. Wheat EST resources for functional genomics of abiotic stress. BioMed Central Genomics 2006; 7:149 http://www.biomedcentral.com/1471-2164/7/149.

[35] Ozturk ZN., Talamé V., Deyholos M., Michalowski CB., Galbraith DW., Gozukirmizi N., Tuberosa R. and Bohnert HJ. (2002) Monitoring large-scale changes in transcript abundance in drought- and salt-stressed barley. Plant Molecular Biology 2002; 48(5-6):551-573.

[36] Pratt LH., Liang C., Shah M., Sun F., Wang H., Reid SP., Gingle AR., Paterson AH., Wing R., Dean R., Klein R., Nguyen HT., Ma H-M., Zhao X., Morishige DT., Mullet JE. and Cordonnier-Pratt M-M. Sorghum expressed sequence tags identify signature genes for drought, pathogenesis, and skotomorphogenesis from a milestone set of 16,801 unique transcripts. Plant Physiology 2005; 139(2):869-884.

[37] Reddy AR., Ramakrishna W., Sekhar AC., Ithal N., Babu PR., Bonaldo MF., Soares MB. and Bennetzen JL. Novel genes are enriched in normalized cDNA libraries from drought-stressed seedlings of rice (Oryza sativa L. subsp. indica cv. Nagina 22). Genome 2002; 45(1):204-211.

[38] Seki M., Narusaka M., Ishida J., Nanjo T., Fujita M., Oono Y., Kamiya A., Nakajima M., Enju A., Sakurai T., Satou M., Akiuama K., Taji T., Yamaguchi-Shinozaki K., Carninci P., Kawai J., Hayashizaki Y. and Shinozaki K. Monitoring the expression profiles of 7000 Arabidopsis genes under drought, cold, and high-saliinity stresses using a full-length cDNA microarray. Plant Journal 2002; 31(3):279-292.

[39] Kilian J., Whitehead D., Horak J., Wanke D., Weinl S., Batistic O., D'Angelo C., Bornberg-Bauer E., Kudla J. and Harter K. The AtGenExpress global stress expression data set: protocols, evaluation and model data analysis of UV-B light, drought and cold stress responses. Plant Journal 2007; 55(3):526-542

[40] Bray EA. Classification of genes differentially expressed during water-deficit stress in Arabidopsis thaliana: an analysis using microarray and differential expression data. Annals of Botany 2002; 89(7):803-811.

[41] Plomion C., Lalanne C., Claverol S., Meddour H., Kohler A., Bogeat-Triboulot M-B., Barre A., Le Provost G., Dumazet H., Jacob D., Bastien C., Dreyer E., de Daruvar A., Guehl J-M., Schmitter J-M., Martin F. and Bonneu M. (2006) Mapping the proteome 
of poplar and application to the discovery of drought-stress responsive proteins. Proteomics 2006; 6(24):6509-6527.

[42] Boominathan P., Shukla R., Kumar A., Manna D., Negi D., Verma PK. and Chattopadhyay D. Long term transcript accumulation during the development of dehydration adaptation in Cicer arietinum. Plant Physiology 2004; 135(3):1608-1620.

[43] Jia J., Fu J., Zheng J., Zhou X., Huai J., Wang J., Wang M., Zhang Y., Chen X., Zhang J., Zhao J., Su Z., Lu Y. and Wang G. Annotation and expression profile analysis of 2073 full-length cDNAs from stress-induced maize (Zea mays L.) seedlings. Plant Journal 2006; 48(5):710-727.

[44] Wisniewski M., Bassett C., Norelli J., Macarisin D., Artlip T., Gasic K., Korban S. Expressed sequence tag analysis of the response of apple (Malus $x$ domestica) to low temperature and water deficit, Physiologia Plantarum 2008; 133:298-317.

[45] Bouchabke-Coussa O., Quashie ML., Seoane-Redondo J., Fortabat MN., Gery C., Yu A., Linderme D., Trouverie J., Granier F., Téoulé E. and Durand-Tardif M. ESKIMO1 is a key gene involved in water economy as well as cold acclimation and salt tolerance. BioMed Central, Plant Biology 2008; doi:10.1186/1471-2229-8-125.

[46] Masle J., Gilmore SR. and Farquhar GD. The ERECTA gene regulates plant transpiration efficiency in Arabidopsis. Nature 2005; 436(Aug 11):866-870.

[47] Franks SJ., Sim S. and Weis AE. Rapid evoluton of flowering time by an annual plant in response to a climate fluctuation. Proceedings of the National Academy of Sciences USA 2007; 104 (4):1278-1282.

[48] Salvi S., Sponza G., Morgante M., Tomes D., Niu X., Fangler KA., Meeley R., Ananiev EV., Svitashev S., Bruggemann E., Li B., Hainey CF., Radovic S., Zaina G., Rafalski JA., Tingey SV., Miao G-H., Phillips RL. and Tuberosa R. Conserved Noncoding genomic Sequences Associated with a Flowering-time Quantitative Trait Locus in Maize. Proceedings of the National Academy of Sciences USA 2007;104(27) 11376-11381.

[49] Mckay JK., Richards JH. and Mitchell-Olds T. Genetics of Drought Adaptation in Arabidopsis thaliana: 1. Pleiotropy Contributes to Genetic Correlations Among Ecological Traits. Molecular Ecology; 2003 12(5) 1137-1151.

[50] Winicov I. cDNA Encoding Putative Zinc Finger Motifs from Salt-Tolerant Alfalfa (Medicago sativa L.) Cells. Plant Physiology 1993; 102(2) 681-682.

[51] Bastola DR., Pethe VV. and Winicov I. Alfin1, A Novel Zinc-Finger Protein in Alfalfa Roots That Binds to Promoter Elements in the Salt-Inducible MsPRP2 Gene. Plant Molecular Biology 1998; 38(6):1123-1135.

[52] Winicov I. Alfin1 Transcription Factor Overespression Enhances Plant Root Growth Under Normal and Saline Conditions and Improves Salt Tolerance in Alfalfa. Planta 2000; 210 (3) 416-422. 
[53] Mori IC., Murata Y., Yang Y., Munemasa S., Wang Y-F., Andreoli S., Tiriac H., Alonso JM., Harper JF., Ecker JR., Kwak JM. and Schroeder JI. CDPKs CPK6 and CPK3 function in ABA regulation of guard cell S-type anion- and Ca2+-permeable channels and stomatal closure. Public Library of Science Biology 2006; 4:e327. doi:10.1371/journal.pbio.0040327.

[54] Pandey S. and Assmann SM. The Arabidopsis putative G protein-coupled receptor GCR1 interacts with the G protein $\alpha$ subunit GPA1 and regulates abscisic acid signaling. The Plant Cell 2003; 16(6):1616-1632.

[55] Klein M., Perfus-Barbeoch L., Frelet A., Gaedeke N., Reinhardt D., Mueller-Roeber B., Martinoia E. and Forestier C. The plant multidrug resistance ABC transporter AtMRP5 is involved in guard cell hormonal signalling and water use. Plant Journal 2003; 33(1):119-129.

[56] Klein M., Geisler M., Suh AJ., Kolukisaoglu Ü., Azevedo L., Plaza S., Curtis MD., Richter A., Weder B., Schulz B. and Martinoia E. Disruption of AtMRP4, a guard cell plasma membrane ABCC-type ABC transporter, leads to deregulation of stomatal opening and increased drought susceptibility. Plant Journal 2004; 39(2):219-236.

[57] Kariola T., Brader G., Helenius E., Li J., Heino P. and Palva ET. EARLY RESPONSIVE TO DEHYDRATION 15, a negative regulator of abscisic acid responses in Arabidopsis. Plant Physiology 2006; 142(4):1559-1573.

[58] Zhang J-Y., Broedkling CD., Blancaflor EB., Sledge MK., Sumner LW. and Wang Z-Y. Overexpression of WXP1, a putative Medicago truncatula AP2 domain-containing transcription factor gene, increases cuticular wax accumulation and enhances drought tolerance in transgenic alfalfa (Medicago sativa). Plant Journal 2005; 42(5): 689-707.

[59] Aharoni A., Dixit S., Jetter R., Thoenes E., van Arkel G. and Pereira A. The SHINE clade of AP2 domain transcription factors activates wax biosynthesis, alters cuticle properties, and confers drought tolerance when overexpressed in Arabidopsis. The Plant Cell 2004; 16(9):2463-2480.

[60] Broun P., Poindexter P., Osborne E., Jiang C-Z. and Riechmann JL. WIN1, a transcriptional activator of epidermal wax accumulation in Arabidopsis. Proceedings of the. National. Academy of Sciences USA 2004; 101(13):4706-4711.

[61] Sivamani E., Bahieldin A., Wraith JM., Al-Niemi T., Syer WE., Ho DT-H. and Qu R. Improved biomass productivity and water use efficiency under water deficit conditions in transgenic wheat constitutively expressing the barley HVA1 gene. Plant Science 2000; 155(2):1-9.

[62] Sun W., Bernard C., van de Cotte B., Van Montagu M. and Vergruggen N. AtHSP17.6A, encoding a small heat-shock protein in Arabidopsis, can enhance osmotolerance upon overexpression. Plant Journal 2001; 27(5):407-415. 
[63] Busk PK. and Pagès M. Regulation of abscisic acid-induced transcription. Plant Molecular Biology 1998; 37(3):425-435.

[64] Shen QJ., Casaretto JA., Zhang P. and Ho T-HD. Functional definition of ABA-response complexes: the promoter units necessary and sufficient for ABA induction of gene expression in barley (Hordeum vulgare L.). Plant Molecular Biology 2004; 54(1): 111-124.

[65] Knight H., Zarka DG., Okamoto H., Thomashow MF. and Knight MR. Abscisic acid induces $\mathrm{CBF}$ gene transription and subsequent induction of cold-regulated genes via the CRT promoter element. Plant Physiology 2004; 135(3):1710-1717.

[66] Haake V., Cook D., Riechmann JL., Pineda O., Thomashow MF. and Zhang JZ. Transcription factor CBF4 is a regulator of drought adaptation in Arabidopsis. Plant Physiology 2002; 130(2):639-648.

[67] Miao YC., Song C-P., Dong FC. and Wang XC. ABA-induced hydrogen peroxide generation in guard cells of Vicia faba. Acta Phytophysiolgia Sinica 2000; 26(1):53-58.

[68] Mittler R., Vanderauwera S., Gollery M. and Van Breusegem F. Reactive oxygen gene network of plants. Trends in Plant Science 2004; 9(10):490-498.

[69] Assmann SM., Snyder JA. and Lee Y-RJ. ABA-deficient (aba1) and ABA-insensitive (abi1-1, abi2-1) mutants of Arabidopsis have a wild-type stomatal response to humidity. Plant Cell \& Environment 2000; 23(4):387-395.

[70] Urao T., Yakubov B., Satoh R., Yamaguchi-Shinozaki K., Seki M., Hirayama T. and Shinozaki K. A transmembrane hybrid-type histidine kinase in Arabidopsis functions as an osmosensor. The Plant Cell 1999; 11(9):1743-1754.

[71] Christmann A., Moes D., Himmelbach A., Yang Y., Tang Y. and Grill E. Integration of abscisic acid signalling into plant responses. Plant Biology 2006; 8(3):314-325.

[72] Mishra NS., Tuteja R. and Tuteja N. Signaling through MAP kinase networks in plants. Archives of Biochemistry and Biophysics 2006; 452(1):55-68.

[73] Yamaguchi-Shinozaki K. and Shinozaki K. The plant hormone abscisic acid mediates the drought-induced expression but not the seed-specific expression of rd22, a gene responsive to dehydration stress in Arabidopsis thaliana. Molecular Genetics and Genomes (formerly called Molecular and General Genetics) 1993; 238(1-2):17-25.

[74] Zhang T., Liu Y., Yang T., Zhang L., Xu S., Xue L. and An L. Diverse signals converge at MAPK cascades in plants. Plant Physiology and Biochemistry 2006; 44(5-6): 274-278.

[75] Ahlfors R., Lang S., Overmyer K., Jaspers P., Brosché M., Tauriainen A., Kollist H., Tuominen H., Belles-Boix E., Piippo M., Inzé D., Palva ET. and Kangasjärvi J. Arabidopsis RADICAL-INDUCED CELL DEATH1 belongs to the WWE protein-protein 
interaction domain protein family and modulates abscisic acid, ethylene and methyl jasmonate responses. The Plant Cell 2004; 16(7):1925-1937.

[76] Yan G., Long H., Song W. and Chen R. Genetic polymorphism of Malus sieversii populations in Xinjiang, China. Genetic Resources and Crop Evolution 2008; doi:10.1007/ s10722-007-9226-5.

[77] Yang J., Yang E. and Yang H. A study on drought resistance of genus Malus seedlings (In Chinese). Acta Agriculturae Boreali-Sinica 1996; 11(2):81-86.

[78] Liu B-H., Cheng L., Ma F-W., Liang D. and Zou Y-J. Influence of rootstock on drought response in young 'Gale Gala' apple (Malus domestica Borkh.) trees. Journal of the Science of Food and Agriculture 2012; doi: 10.1002/jsfa.5647.

[79] Cornille A., Gladieux P., Smulders MJM., Roldán-Ruiz I., Laurens F. et al. New insight into the history of domesticated apple: secondary contribution of the European wild apple to the gnome of cultivates varieties. Public Library of Science, Genetics, 2012; doi:10.1371/journal.pgen.1002703.

[80] Forsline PL., Aldwinckle HS., Dickson EE., Luby JJ. and Hokanson SC. Collection, Maintenance, Characterization and Utilization of Wild Apples of Central Asia. In: Janick J. (ed.) Horticultural Reviews. John Wiley \& Sons, Hoboken, NJ 2003; 29:1-62.

[81] Volk GM., Richards CM., Reilley AA., Henk AD., Forsline PL. and Aldwinckle HS. Ex Situ Conservation of Vegetatively Propagated Species: Development of a Seedbased Core Collection for Malus sieversii. Journal of the American Society for Horticultural Society 2005; 130(2):203-210.

[82] Richards CM., Volk GM., Reeves PA., Reilley AA., Forsline PL. and Aldwinckle HS. Selection of Stratified Core Sets Representing Wild Apple (Malus sieversii). Journal of the American Society for Horticultural Science 2009; 134(2):228-235.

[83] Richards CM., Volk GM., Reilley AA., Henk AD., Lockwood DR., Reeves PA. and Forsline PL. Genetic Diversity and Population Structure in Malus sieversii, a Wild Progenitor Species of Domesticated Apple. Tree Genetics \& Genomes 2009; 5(2): 339-347.

[84] Bassett CL., Glenn DM., Forsline PL., Wisniewski ME. and Farrell Jr. RE. Characterizing water use efficiency and water deficit responses in apple (Malus $\times$ domestica Borkh. and Malus sieversii Ledeb.) M. Roem. HortScience 2011; 46(8):1079-1084.

[85] Nemeskéri E., Sárdi É,, Szabó T. and Nyéki J. Ecological drought resistance and adaptability of apple varieties. International Journal of Horticultural Science 2010; 16(1):113-122.

[86] Bassett CL., Wisniewski ME., Artlip TA., Norelli JL., Renaut J. and Farrell, Jr RE. Global analysis of genes regulated by low temperature and photoperiod in peach bark. Journal of the American Society for Horticultural Science 2006; 131(4):551-563. 
[87] Tong Z., Gao Z., Wang F., Zhou J. and Zhang Z. Selection of reliable reference genes for gene expression studies in peach using real-time PCR. BioMed Central Molecular Biology 2009; doi: 10.1186/1471-2199-10-71.

[88] Higo K., Ugawa Y., Iwamoto M. and Korenaga T. Plant cis-acting regulatory DNA elements (PLACE) database:1999. Nucleic Acids Research 1999; 27(1):297-300.

[89] Lescot M., Déhais P.,Thijs G., Marchal K., Moreau Y., Van de Peer Y., Rouzé P. and Rombauts S. PlantCARE, a database of plant cis-acting regulatory elements and a portal to tools for in silico analysis of promoter sequences. Nucleic Acids Research 2002; 30(1):325-327.

[90] Mohanty B., Krishnan SP., Swarup S. and Bajic VB. Detection and preliminary analysis of motifs in promoters of anaerobically induced genes of different plant species. Annals of Botany 2005; 96(4):669-681.

[91] Maleck K., Levine A., Eulgem T., Morgan A., Schmid J., Lawton KA., Dangl JL. and Dietrich RA. The transcriptome of Arabidopsis thaliana during systemic acquired resistance. Nature Genetics 2000; 26(4):403-410.

[92] Lebel E., Heifetz P., Thorne L., Uknes S., Ryals J. and Ward E. Functional analysis of regulatory sequences controlling PR-1 gene expression in Arabidopsis. Plant Journal 1998; 16(2):223-233.

[93] Kobayashi T., Nakayama Y., Itai RN., Nakanishi H., Yoshihara T., Mori S. and Nishizawa NK. Identification of novel cis-acting elements, IDE1 and IDE2, of the barley ISD2 gene promoter conferring iron-deficiency-inducible, root-specific expression in heterogeneous tobacco plants. Plant Journal 2003; 36(6):780-793.

[94] Pastuglia M., Roby D., Dumas C. and Cock JM. Rapid induction by wounding and bacterial infection of an $S$ gene family receptor-like kinase in Brassica oleracea. The Plant Cell 1997; 9(1):1-13.

[95] Shen Q. and Ho T-HD. Functional dissection of an abscisic acid (ABA)-inducible gene reveals two independent ABA-responsive complexes each containing a G-box and novel cis-acting element. The Plant Cell 1995; 7(3):295-307.

[96] Satoh R., Nakashima K., Seki M., Shinozaki K., and Yamaguchi-Shinozaki K. ACTCAT, a novel cis-acting element for proline- and hypoosmolarity-responsive expression of the ProDH gene encoding proline dehydrogenase in Arabidopsis. Plant Physiology 2002; 130(2):709-719.

[97] Abe H., Yamaguchi-Shinozaki K., Urao T., Iwasaki T., Hosokawa D. and Shinozaki K. Role of Arabidopsis MYC and MYB homologs in drought- and abscisic acid-regulated gene expression. The Plant Cell 1997; 9(10):1859-1868.

[98] Yamaguchi-Shinozaki K. and Shinozaki K. A novel cis-acting element in an Arabidopsis gene is involved in responsiveness to drought, low-temperature, or high-salt stress. The Plant Cell 1994; 6(2):251-264. 
[99] Baker SS., Wilhelm KS. and Thomashow MF. The 5N region of Arabidopsis thaliana cor15a has cis-acting elements that confer cold-, drought- and ABA-regulated gene expression. Plant Molecular Biology 1994; 24(5):701-713. 
